\title{
Laparoskopisk gastrisk bypassoperasjon versus livsstilsbehandling av unge med sykelig overvekt
}

ORIGINALARTIKKEL

\section{JØRAN HJELMESAETH}

E-post: joran.hjelmeseth@siv.no

Senter for sykelig overvekt i Helse Sør-Øst

Sykehuset i Vestfold

og

Avdeling for endokrinologi, sykelig overvekt og forebyggende medisin

Universitetet i Oslo

Han har bidratt med første utkast til manus, idé, utforming/design, analyse og tolking av data, litteratursøk, revisjon av manuset og innsending av siste manusversjon.

Jøran Hjelmesæth er dr.med., senterleder og professor. Han er leder av Nasjonalt råd for ernæring og fagansvarlig (study chair) for 4XL-studien.

Forfatteren har fylt ut ICMJE-skjemaet og oppgir ingen interessekonflikter.

\section{JENS KRISTOFFER HERTEL}

Senter for sykelig overvekt i Helse $\ \emptyset \mathrm{r}-\emptyset$ st

Sykehuset i Vestfold

Han har bidratt med deltakelse i styringsgruppen, utforming/design, analyse og tolking av data, utarbeiding/revisjon av manuset og figurer samt godkjenning av innsendte manusversjon. Jens Kristoffer Hertel er ph.d., seniorforsker og leder forskningsavdelingen. Forfatteren har fylt ut ICMJE-skjemaet og oppgir ingen interessekonflikter.

\section{ANE HJETLAND HOLT}

Senter for sykelig overvekt i Helse Sør- Øst

Sykehuset i Vestfold

Hun har bidratt med datainnsamling, tolking av data, revisjon av manuset og godkjenning av innsendte manusversjon.

Ane Hjetland Holt er lege.

Forfatteren har fylt ut ICMJE-skjemaet og oppgir ingen interessekonflikter.

\section{BEATE BENESTAD}

Senter for sykelig overvekt i Helse Sør-Øst

Sykehuset i Vestfold

Hun har bidratt med datainnsamling, tolking av data, litteratursøk, revisjon av manuset og godkjenning av innsendte manusversjon.

Beate Benestad er lege og ph.d.-stipendiat.

Forfatteren har fylt ut ICMJE-skjemaet og oppgir ingen interessekonflikter. 
Avdeling for kreft og kirurgi

Sykehuset i Vestfold

Han har bidratt med utføring av vektreduserende kirurgi, datainnsamling, tolking av data, revisjon av manuset og godkjenning av innsendte manusversjon.

Lars Thomas Seeberg er ph.d. og gastrokirurg med spesialkompetanse i vektreduserende kirurgi.

Forfatteren har fylt ut ICMJE-skjemaet og oppgir ingen interessekonflikter.

\section{MORTEN LINDBERG}

Sentrallaboratoriet

Sykehuset i Vestfold

Han har bidratt med datainnsamling, analyse og tolking av data, litteratursøk, revisjon av manuset og godkjenning av innsendte manusversjon.

Morten Lindberg er ph.d. og overlege.

Forfatteren har fylt ut ICMJE-skjemaet og oppgir ingen interessekonflikter.

\section{ERLING HALVORSEN}

Radiologisk avdeling

Sykehuset i Vestfold

Han har bidratt med datainnsamling, analyse og tolking av data, revisjon av manuset og godkjenning av innsendte manusversjon.

Erling Halvorsen er overbioingeniør.

Forfatteren har fylt ut ICMJE-skjemaet og oppgir ingen interessekonflikter.

\section{PÉTUR BENEDIKT JÚLÍUSSON}

Helseregisterforskning- og utvikling

Folkehelseinstituttet, Bergen

og

Barne- og ungdomsklinikken

Haukeland universitetssjukehus

og

Klinisk institutt 2

Universitetet i Bergen

Han har bidratt med deltakelse i styringsgruppen, analyse og tolking av data, revisjon av manuset og godkjenning av innsendte manusversjon.

Pétur Benedikt Júlíusson er ph.d., avdelingsdirektør, overlege og professor. Han har

spesialkompetanse i pediatrisk endokrinologi og fedme hos barn og unge.

Forfatteren har fylt ut ICMJE-skjemaet og oppgir ingen interessekonflikter.

\section{RUNE SANDBU}

Senter for sykelig overvekt i Helse $\ \emptyset \mathrm{r}-\emptyset$ st

Sykehuset i Vestfold

og

Avdeling for kreft og kirurgi

Sykehuset i Vestfold

Han har bidratt med utføring av vektreduserende kirurgi, idé, utforming/design, tolking av data, revisjon av manuset og godkjenning av innsendte manusversjon.

Rune Sandbu er ph.d., seniorforsker, avdelingssjef og ansvarlig for kirurgidelen i 4XL-studien.

Forfatteren har fylt ut ICMJE-skjemaet og oppgir ingen interessekonflikter.

\section{SAMIRA LEKHAL}

Senter for sykelig overvekt i Helse Sør-Øst

Sykehuset i Vestfold

Hun har bidratt med utforming/design, datainnsamling, tolking av data, litteratursøk, revisjon av manuset og godkjenning av innsendte manusversjon.

Samira Lekhal er ph.d., seniorforsker og seksjonsoverlege. Hun er studieleder (principal investigator) for 4 XL-studien.

Forfatteren har fylt ut ICMJE-skjemaet og oppgir ingen interessekonflikter. 


\section{BAKGRUNN}

Kunnskapsgrunnlaget om effekten av og komplikasjoner ved vektreduserende kirurgi hos ungdom er mangelfullt. Hovedformålet med 4XL-studien er å avklare om laparoskopisk Roux-en-Y gastrisk bypassoperasjon (LGBP) kombinert med livsstilsintervensjon er en sikker og effektiv behandlingsmetode.

\section{MATERIALE OG METODE}

Materialet er hentet fra en pågående ikke-randomisert intervensjonsstudie av ungdom med sykelig overvekt, der man sammenlikner effektene av gastrisk bypass kombinert med livsstilsintervensjon og livsstilsintervensjon alene.

\section{RESULTATER}

Totalt 39 pasienter ( $64 \%$ jenter) behandlet med gastrisk bypass og 96 pasienter ( $57 \%$ jenter) behandlet med livsstilsintervensjon ble undersøkt før og ett år etter behandlingsstart. Ved inklusjon var gjennomsnittsalderen (SD) hhv. 16,7 år (1,0) vs. 15,6 år (1,3), og gjennomsnittlig BMI 45,6 kg/m $(4,4)$ vs. $43,3 \mathrm{~kg} / \mathrm{m}^{2}(4,1)$ i de to gruppene. Gjennomsnittlig prosentuelt vekttap var $30 \%$ ( $95 \%$ KI 27 til 33) etter kirurgi versus en vektøkning på 1\% (95\% KI -1 til 3) i kontrollgruppen. Forskjellen mellom gruppene var $31 \%$ ( $95 \%$ KI 27 til 34, p < o,oo1). Kardiometabolske risikofaktorer bedret seg kun etter kirurgi. Etter gastrisk bypass ble det registrert to tidlige ( $<6$ uker) mindre alvorlige komplikasjoner. Ett år etter kirurgi hadde totalt $4(10 \%)$ pasienter anemi, $8(21 \%)$ jernmangel og $4(10 \%)$ lave vitamin $\mathrm{B}_{12}$-verdier. 20 av 33 testede $(61 \%)$ pasienter hadde lavt totimers-blodsukker $(<2,8 \mathrm{mmol} / \mathrm{L})$ etter glukosebelastning.

\section{FORTOLKNING}

Resultatene støtter tidligere studier som har vist at gastrisk bypass er assosiert med betydelig vektreduksjon hos unge pasienter med sykelig overvekt. 4XL-studien er foreløpig for liten og oppfølgingstiden for kort til å kunne vurdere risikoen for langtidskomplikasjoner.

Sykelig overvekt hos ungdom er assosiert med økt risiko for følgesykdommer som ikkealkoholisk fettleversykdom, type 2-diabetes, hjerte- og karsykdom, psykisk sykdom, sykelig overvekt i voksen alder og kortere levetid $(1,2)$. Effektiv behandling kan derfor gi store gevinster, både for enkeltindividet og samfunnet (3).

I konservativ behandling av sykelig overvekt hos ungdom benyttes tverrfaglig tilnærming og familiebasert atferdsterapi for å støtte endringer i levevaner knyttet til kosthold og fysisk aktivitet. Dette gir en gjennomsnittlig lav til moderat vektreduksjon $(4,5)$.

Hos voksne har vektreduserende kirurgi gitt gode resultater, med varig vekttap og bedring av følgesykdommer, men også økt risiko for komplikasjoner på kort og lang sikt $(6,7)$. Før 4XL-studien startet opp i 2009, manglet tilstrekkelig dokumentasjon for effekt og komplikasjoner av vektreduserende kirurgi hos ungdom (8). Kunnskapsgrunnlaget elleve år senere er fortsatt mangelfullt $(3,9)$.

Det primære forskningsspørsmålet i 4XL-studien er å avklare om laparoskopisk Roux-en-Y gastrisk bypassoperasjon (i det følgende bare kalt gastrisk bypass) kombinert med livsstilsintervensjon er en effektiv vektreduserende og sikker behandlingsmetode. I denne artikkelen sammenliknes resultatene av vektreduserende kirurgi og ikke-kirurgisk behandling ett år etter behandlingsstart.

\section{Materiale og metode}

4XL-studien er en pågående klinisk prospektiv intervensjonsstudie av pasienter i alderen 
13-18 år som søker behandling ved Senter for sykelig overvekt i Helse Sør- $\emptyset$ st, Sykehuset i Vestfold - et regionalt kompetansesenter for helhetlig og tverrfaglig behandling av sykelig overvekt hos barn, unge og voksne. Studien startet i 2009, og i denne analysen brukes data fra pasienter inkludert i perioden 8.10.2009-19.4.2018.

Barn, unge og familier med sykelig overvekt kan henvises både fra primærhelsetjenesten og sekundærhelsetjenesten til behandling på kompetansesenteret. Ved første konsultasjon blir alle familier informert og spurt om å delta i Barnefedmeregisteret i Vestfold (BFR), et samtykkebasert, prospektivt register, der man samler inn personopplysninger og biologisk materiale i en forskningsbiobank (4). Behandlingstilbudet er organisert rundt et tverrfaglig team med lege, klinisk ernæringsfysiolog, sykepleier, spesialfysioterapeut og helsepedagog (appendiks). Hovedhensikten med 4XL-studien er å avklare om gastrisk bypass kombinert med livsstilsbehandling gir større helsegevinst enn livsstilsbehandling alene på kort og lang sikt (1-10 år) samt å kartlegge komplikasjoner etter inngrepet.

Både rekrutteringen av egnede pasienter til studien og frafallet av pasienter har vært lavere enn forventet. Studiens styringsgruppe har derfor bestemt at foreliggende ettårsdata bør analyseres og publiseres.

\section{DELTAKERE}

Pasienter som har ønske om kirurgisk behandling og som har gjennomført minst ett år tverrfaglig konservativ behandling i norsk helsetjeneste uten tilfredsstillende resultat, kan henvises til vurdering for inklusjon i 4XL-studien. De som inkluderes, blir behandlet med gastrisk bypass med standardlengde på Roux-slyngen $(120 \mathrm{~cm}) \mathrm{i}$ tillegg til standard livsstilsbehandling (4). Alle anastomoser anlegges med stiftemaskin.

Inklusjonskriterier er alder $13-18$ år, $\mathrm{BMI} \geq 40 \mathrm{~kg} / \mathrm{m}^{2}$ eller $\mathrm{BMI} \geq 35 \mathrm{~kg} / \mathrm{m}^{2}$ samt at man har minst én følgesykdom og er i Tanner-stadium 4-5 i pubertetsutviklingen.

Eksklusjonskriterier er BMI $\geq 55 \mathrm{~kg} / \mathrm{m}^{2}$, betydelig risiko for mangel på etterlevelse, spesifikke fedmesyndromer, fedme forårsaket av hjerneskade eller alvorlig generell sykdom.

Kontrollgruppen (de som får livsstilsbehandling) består av pasienter som ikke har ytret $\emptyset$ nske om kirurgi, men som har takket ja til deltakelse i Barnefedmeregisteret i Vestfold og som blir konservativt behandlet ved senteret i samme periode. De må også tilfredsstille inklusjonskriteriene (alder, BMI) for kirurgi. Noen av resultatene etter konservativ behandling er publisert tidligere (4).

UTFALL

Primærutfall i denne analysen er BMI og prosentuelt vekttap ett år etter kirurgi/behandlingsstart. Sekundærutfall er kardiometabolske risikofaktorer (dyslipidemi, inflammasjon, hypertensjon, dysglykemi, fettleversykdom), tidlige postoperative komplikasjoner (gradert fra mindre alvorlige (grad I) til død (grad IV) i henhold til Contracted Accordion Classification system innen seks uker etter operasjon), beinmineraltetthet, anemi, samt forskjellige vitamin- og mineralmangler (tiamin, vitamin $\mathrm{B}_{12}$, vitamin D, jern, kalsium) og totimers- blodsukker etter glukosebelastningstest. Primærutfallene ble supplert med midjeomkrets og kroppssammensetning (fettprosent, fettmasse, fettfri masse).

\section{MÅLEMETODER}

Høyde måles med stadiometer (Seca 264, Seca, Hamburg, Tyskland). Vekt og kroppssammensetning blir målt med bioimpedansanalyse (BC-418 Segmental Body Composition Analyzer, Tanita Corporation, Tokyo, Japan). Midjemål blir målt horisontalt midt mellom nederste ribbein og hoftekammen. Blodtrykk måles med Dinamap ProCare (GE Healthcare, Buckinghamshire, Storbritannia), og gjennomsnittet av tre målinger blir kalkulert. Røyking er selvrapportert (ja/nei) ved inklusjon.

Medisinsk biokjemiske rutineanalyser blir utført ved Sentrallaboratoriet, Sykehuset i 
Vestfold. Laboratoriet er akkreditert etter standarden NS-EN ISO 15189. LDL-kolesterol $\geq$ $2,8 \mathrm{mmol} / \mathrm{L}$ og non-HDL-kolesterol $\geq 3,1 \mathrm{mmol} / \mathrm{L}$ ble regnet som forh $ø y e t$, med $ø \mathrm{kt}$ risiko for hjerte- og karsykdom (10). Normal glukosetoleranse, prediabetes og type 2-diabetes er definert som henholdsvis HbA1c < 5,7\%, 5,7-6,4\% og $\geq 6,5 \%$ (11). Hypertensjon er definert som systolisk blodtrykk $\geq 130 \mathrm{~mm}$ Hg eller diastolisk blodtrykk $\geq 80 \mathrm{~mm} \mathrm{Hg}$ (12).

Beinmineraltetthet (BMD-z-skår) og beinmineralinnhold (BMC) i totalkropp måles med dobbel røntgenabsorpsjonsmetri (DXA) med et Hologic Delphi W-instrument (Hologic, Marlborough, MA, USA). Alaninaminotransferaseverdier i serum (s-ALAT) høyere enn $34 \mathrm{U} / \mathrm{L}$ hos gutter og $24 \mathrm{U} / \mathrm{L}$ hos jenter ble brukt som surrogatmark $ø$ r for fettleversykdom (13).

\section{UTVALGSST ØRRELSE}

På bakgrunn av egen klinisk erfaring forventet vi en gjennomsnittlig vektreduksjon på $25 \%$ (10 BMI-enheter) i kirurgigruppen og inntil 10\% (4 BMI-enheter) i livsstilsgruppen (standardavvik(SD) 5). Totalt 42 pasienter måtte gjennomføre studien (21 opererte og 21 konservativt behandlet) for å vise en slik forskjell (6 BMI-enheter) med over 9o \% styrke og signifikansnivå (alfa) på o,01. Forventet frafall var opptil 30 \%. For også å kunne vurdere andel alvorlige postoperative komplikasjoner ble det planlagt inklusjon av 50 pasienter til kirurgi.

\section{STATISTISKE METODER}

Sammenlikning av behandlingsgrupper før behandlingsstart ble utført med t-test, MannWhitney-test eller Fishers eksakte test. Endringer fra før behandlingsstart til ettårsoppfølgingen ble analysert med parede t-tester eller McNemars test. Sammenlikning av gruppene etter ett år ble gjort med kovariansanalyse (ANCOVA), med justering for utgangsverdi av avhengig variabel, uparet t-test, eller logistisk regresjon med utgangsverdi av avhengig variabel som kovariat. P-verdier $<0,05$ ble ansett som statistisk signifikante.

\section{ETIKK}

4XL-studien er godkjent av Regional komité for medisinsk og helsefaglig forskningsetikk (REK) Sør-Øst (referanse S-08584c 2008/14165) og tilrådd av personvernombudet for forskning og Norsk senter for forskningsdata (prosjekt nr. 21242). Barnefedmeregisteret i Vestfold er godkjent av Regional komité for medisinsk og helsefaglig forskningsetikk (S-08742C 2008/19081), Norsk senter for forskningsdata, har konsesjon fra Datatilsynet (20789 grh/rh) og er tilrådd av lokalt personvernombud. Registerets forskningsbiobank er godkjent av Helsedirektoratet. Studien ble registrert i Clinical Trials 18. juni 2009

(NCToog23819).

\section{Resultater}

Til sammen 510 unge pasienter startet behandling ved Senter for sykelig overvekt i Helse Sør- $\emptyset$ st, Sykehuset i Vestfold i perioden 8.10.2009-19.4.2018 (figur 1). Totalt 19 av 60 pasienter henvist til inklusjon for kirurgi var ikke egnet. 41 pasienter ble inkludert og operert, og 39 møtte til ettårskontroll. Totalt 139 pasienter i livsstilsgruppen startet behandling, og 96 møtte til ettårskontroll. Pasienter i livsstilsgruppen som møtte til ettårskontroll ( $n=96)$ var litt yngre enn de som ikke møtte $(n=43)$. Det var også en tendens til at de som ikke møtte, hadde høyere vekt og midjemål (tabell 1 ). 


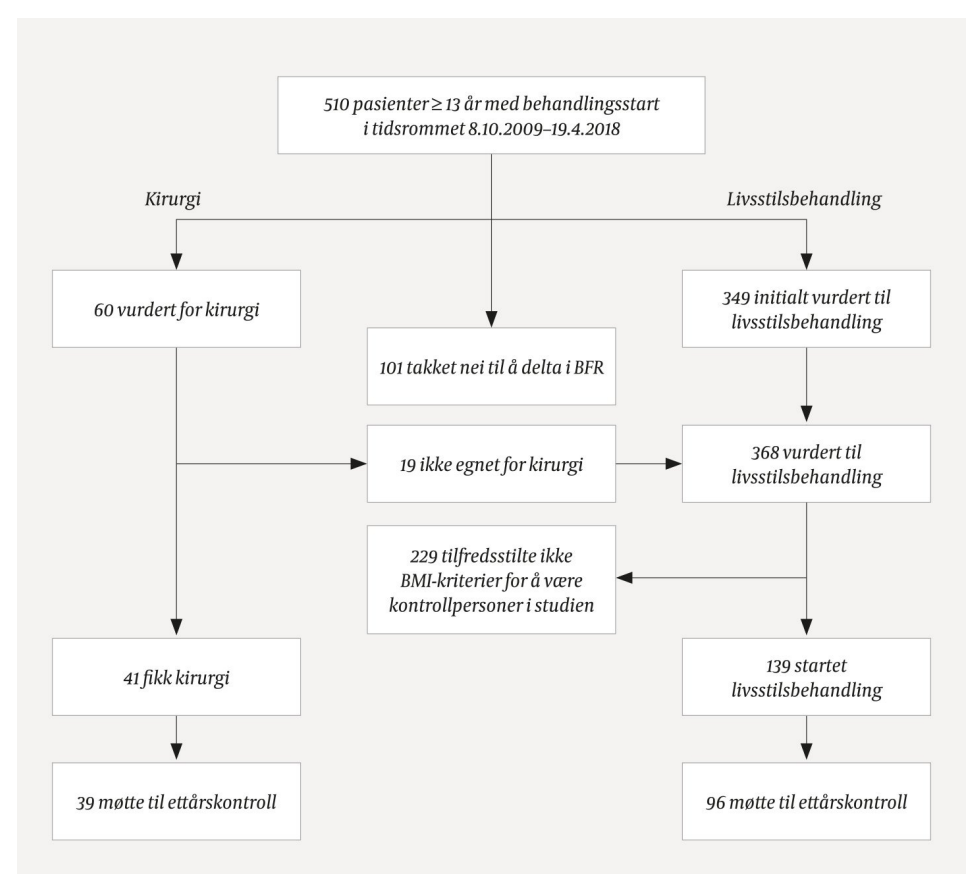

Figur 1 Fordeling av pasienter i alderen 13-18 år med BMI $35 \mathrm{~kg} / \mathrm{m}^{2}$ eller mer til livsstilsbehandling ( $\mathrm{n}$ $=139)$ eller kirurgi $(n=41)$ blant 510 unge pasienter som startet behandling ved Senter for sykelig overvekt i perioden 8.10.2009-19.4.2018. BFR = Barnefedmeregisteret $i$ Vestfold.

\section{Tabell 1}

Utgangskarakteristika for inkluderte ungdommer 13-18 år med sykelig overvekt som startet med livsstilsbehandling ved Senter for sykelig overvekt i Vestfold i perioden

8.10.2009-19.4.2018. Data presenteres separat for pasienter som møtte og ikke møtte til ettårskontroll. Verdier er gjennomsnitt(SD) dersom annet ikke er angitt

\begin{tabular}{|crr|}
\hline & $\begin{array}{r}\text { Livsstilsgruppen } \\
\text { møtt til ettårskontroll } \\
(\mathbf{n}=\mathbf{9 6})\end{array}$ & $\begin{array}{r}\text { Livsstilsgruppen } \\
\text { ikke møtt til } \\
\text { ettårskontroll (n = 43) }\end{array}$ \\
\hline Kjønn & $55(57)$ & $22(51)$ \\
\hline Jente, antall (\%) & $41(43)$ & $21(49)$ \\
\hline Gutt, antall (\%) & $15,6(1,3)$ & $16,1(1,4)$ \\
\hline Alder (år) & & $130(17)$ \\
\hline $\begin{array}{l}\text { Antropometri og } \\
\text { kroppssammensetning }\end{array}$ & $124(20)$ & $172(10)$ \\
\hline Vekt $(\mathrm{kg})$ & $169(9)$ & $44,0(3,1)$ \\
\hline Høyde $(\mathrm{cm})$ & $43,3(4,1)$ & $124(10)$ \\
\hline Kroppsmasseindeks $\left(\mathrm{kg} / \mathrm{m}^{2}\right)$ & $120(13)$ & $49(5)$ \\
\hline Midjemål $(\mathrm{cm})$ & $49(6)$ & $64(11)$ \\
\hline Fettprosent & $61(14)$ & \\
\hline Fettmasse $(\mathrm{kg})$ &
\end{tabular}

Før behandlingsstart var pasientene i kirurgigruppen $(n=39)$ gjennomsnittlig ett år eldre og 2 BMI-poeng tyngre enn livsstilsgruppen $(n=96)$ (tabell 2). Kjønnsfordeling, gjennomsnittlig midjeomkrets, fettmasse, fettprosent og andel pasienter med ulike kardiometabolske risikofaktorer, var ikke signifikant forskjellige mellom gruppene (tabell 2).

\section{Tabell 2}


Utgangskarakteristika for inkluderte ungdommer 13-18 år med sykelig overvekt som startet behandling ved Senter for sykelig overvekt i Vestfold i perioden 8.10.2009-19.4.2018 og møtte til ettårskontroll. Verdier er antall (\%) dersom annet ikke er angitt.

\begin{tabular}{|c|c|c|c|}
\hline \multirow{3}{*}{$\begin{array}{l}\text { Kjønn } \\
\end{array}$} & \multicolumn{2}{|c|}{ Kirurgi + Livsstilsintervensjon } & \multirow[t]{2}{*}{ P-verdi } \\
\hline & \multicolumn{2}{|l|}{$\begin{array}{r}\text { livsstilsintervensjon } \\
(\mathbf{n}=39)\end{array}$} & \\
\hline & & & \\
\hline Jente & $25(64)$ & $55(57)$ & \multirow[t]{2}{*}{0,56} \\
\hline Gutt & $14(36)$ & $41(43)$ & \\
\hline \multicolumn{4}{|l|}{ Alder (år) } \\
\hline $\begin{array}{l}\text { Median (fra lavest til } \\
\text { høyest verdi) }\end{array}$ & $16,9(14,2-18,0)$ & $15,6(13,0-18,0)$ & $<0,001$ \\
\hline \multicolumn{4}{|l|}{$\begin{array}{l}\text { Antropometri og } \\
\text { kroppssammensetning, } \\
\text { gjennomsnitt (SD) }\end{array}$} \\
\hline Kroppsvekt (kg) & $132(14)$ & $124(20)^{2}$ & 0,024 \\
\hline Høyde $(\mathrm{cm})$ & $170(8)$ & $169(9)^{2}$ & 0,42 \\
\hline $\operatorname{BMI}\left(\mathrm{kg} / \mathrm{m}^{2}\right)$ & $45,6(4,4)$ & $43,3(4,1)^{2}$ & 0,004 \\
\hline Midjeomkrets $(\mathrm{cm})$ & $124(11)$ & $120(13)^{3}$ & 0,098 \\
\hline Fettprosent & $50(6)^{4}$ & $49(6)^{5}$ & 0,53 \\
\hline Fettmasse $(\mathrm{kg})$ & $66(11)^{4}$ & $61(14)^{5}$ & 0,075 \\
\hline Fettfri masse $(\mathrm{kg})$ & $66(10)^{4}$ & $63(12)^{5}$ & 0,13 \\
\hline \multicolumn{4}{|l|}{$\begin{array}{l}\text { Kardiometabolske } \\
\text { riskofaktorer }\end{array}$} \\
\hline Hypertensjon & $8(21)$ & $19(20)$ & 1,00 \\
\hline $\begin{array}{l}\text { Hyperkolesterolemi (non- } \\
\text { HDL) }\end{array}$ & $22(56)$ & $65(68)$ & 0,24 \\
\hline $\begin{array}{l}\text { C-reaktivt protein } \\
\geq 3 \mathrm{mg} / \mathrm{L}\end{array}$ & $31(80)$ & $66(70)^{2}$ & 0,39 \\
\hline Røyker & $8(21)$ & $10(10)^{3}$ & 0,18 \\
\hline Type 2-diabetes & $3 / 38(8)$ & $1(1)$ & \multirow[t]{3}{*}{0,12} \\
\hline Prediabetes & $6 / 38(16)$ & $14(15)^{2}$ & \\
\hline Normal glukosetoleranse & $29 / 38(76)$ & $79(84)^{2}$ & \\
\hline \multicolumn{4}{|l|}{ Fettleversykdom } \\
\hline $\begin{array}{l}\text { ALAT > } 24 \mathrm{U} / \mathrm{L} \text { jenter/> } \\
34 \mathrm{U} / \mathrm{L} \text { gutter }\end{array}$ & $17 / 39(44)$ & $43 / 95(45)$ & 1,00 \\
\hline
\end{tabular}

't-test, Mann-Whitney-test eller Fishers eksakte test.

${ }^{2} n=94$

${ }^{3} n=92$

${ }^{4} \mathrm{n}=37$

${ }^{5} n=93$

\section{PRIMAERUTFALL}

BMI falt gjennomsnittlig 14,1 ( $95 \%$ KI 12,7 til 15,6) poeng i kirurgigruppen og o,4 ( $-0,3$ til 1,2) poeng i livsstilsgruppen. Estimert forskjell mellom gruppene etter ett år var 13,2 (11,7 til 14,7) BMI-poeng. Totalt $23(25 \%)$ og $13(14 \%)$ pasienter i livsstilsgruppen hadde et fall i BMI på minst $5 \%$ og $10 \%$, sammenliknet med henholdsvis $100 \%$ og $97 \%$ i kirurgigruppen (figur 2 ). Gjennomsnittlig prosentuelt vekttap var $30 \%$ (27 til 33\%) i kirurgigruppen sammenliknet med en vektøkning på $1 \%(-1$ til $3 \%$ ) i livsstilsgruppen, observert forskjell $31 \%(27$ til 34\%), p $<$ o,oo1 (tabell 3 ). 


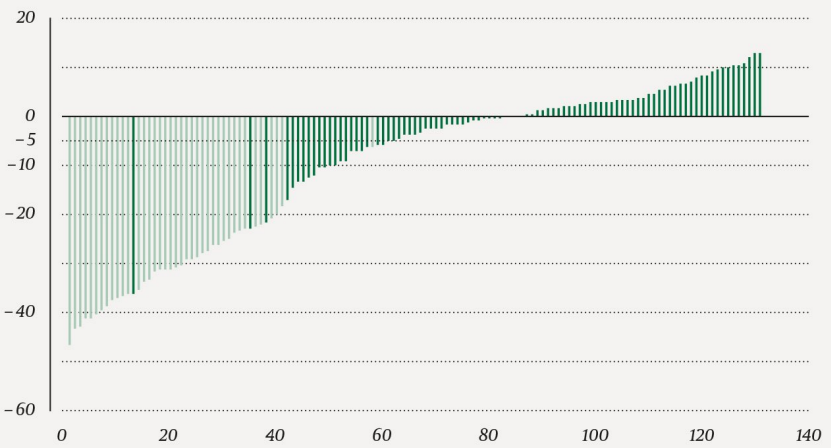

Figur 2 Individuell variasjon i prosentuell endring $i$ BMI ett år etter behandlingsstart $i$ de to behandlingsgruppene. Hver stolpe representerer endring hos én enkelt pasient. Delvis overlapp med data fra (4) for livsstilsgruppen.

\section{Tabell 3}

Observerte primære (BMI og prosentuell vektendring) og sekundære utfallsmål ved ettårskontroll og utgangsverdijusterte estimerte forskjeller eller observerte prosentuelle forskjeller mellom gruppene. Inkludert er ungdommer med sykelig overvekt som startet behandling ved Senter for sykelig overvekt i Vestfold i perioden 8.10.2009-19.4.2018 og som møtte til ettårskontroll. Verdier er gjennomsnitt(SD) dersom annet ikke er angitt.

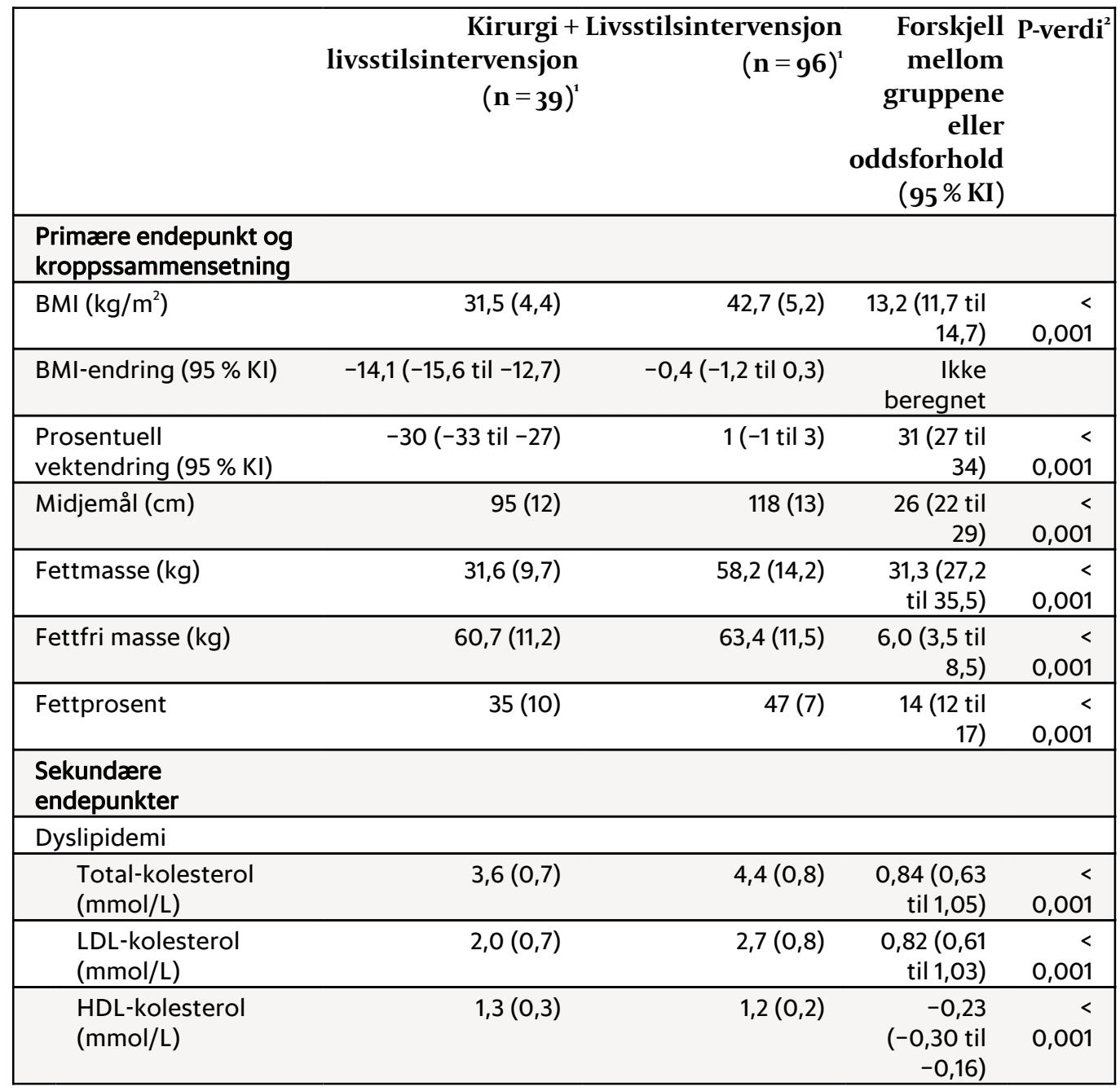




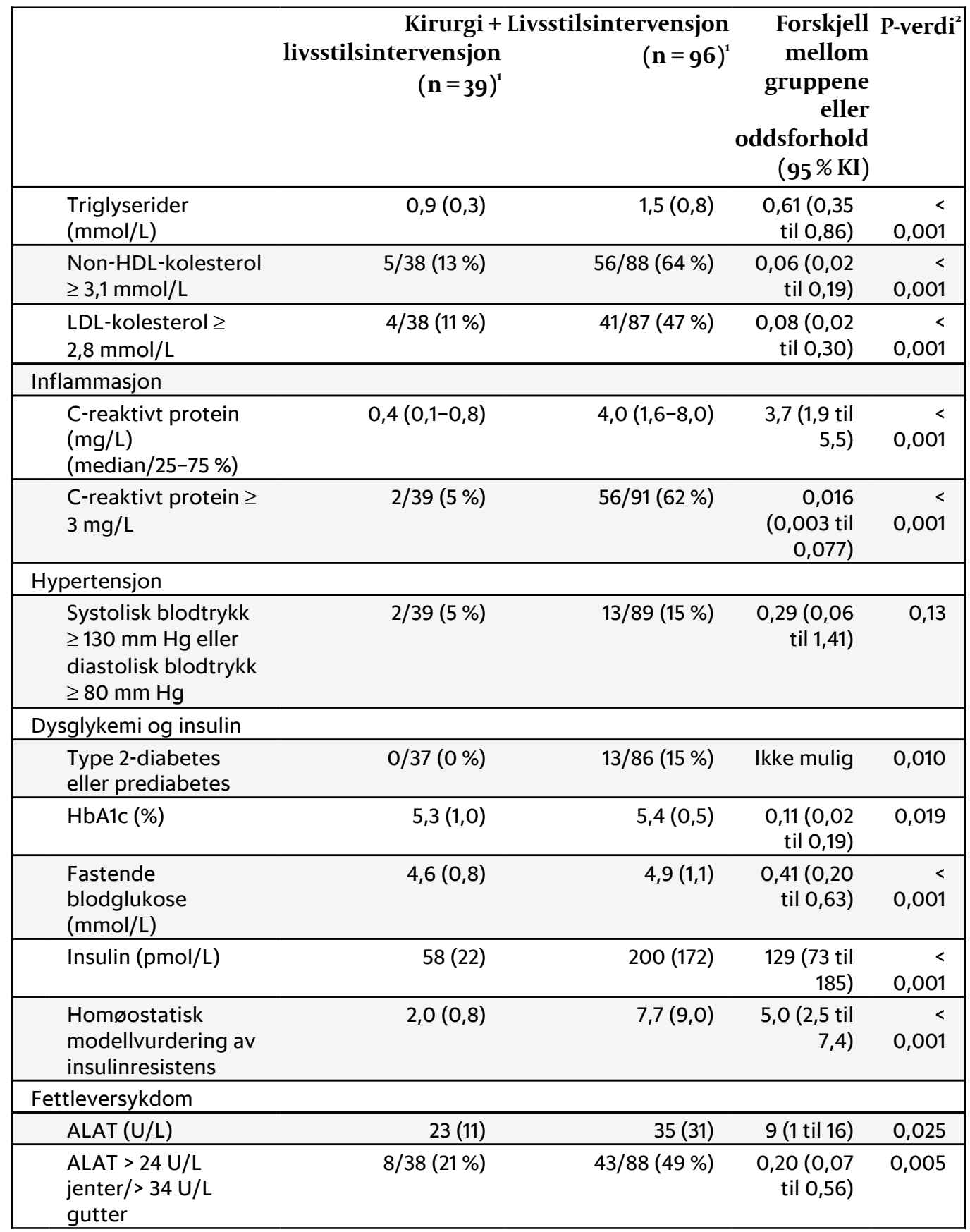

${ }^{1}$ De fleste ettårsverdier er analysert for minst 37 av 39 (95\%) pasienter i kirurgigruppen (unntatt insulin og Homøostatisk modellvurdering av insulinresistens (HOMA-IR), 36/39), og minst 88 av 96 (92 \%) pasienter i kontrollgruppen (unntatt midjemål, 81/96, insulin og HOMA-IR, 85/96).

${ }^{2}$ Endringer fra før behandlingsstart til ettårsoppfølging ble analysert med parede t-tester. Sammenlikning av gruppene etter ett år ble gjort med kovariansanalyse (ANCOVA) med justering for utgangsverdi av avhengig variabel, uparet t-test, kvantilregresjon eller logistisk regresjon med utgangsverdi av avhengig variabel som kovariat.

\section{SEKUNDARUTFALL}

Andelen pasienter med hyperkolesterolemi eller forhøyet C-reaktivt protein $(\geq 3 \mathrm{mg} / \mathrm{L})$ sank signifikant mer i kirurgigruppen enn i livsstilsgruppen, alle oddsforhold (OR)<0,og (tabell 3). Alle pasienter med dysglykemi (type 2-diabetes eller prediabetes) hadde normoglykemi ett år etter kirurgi, og ingen med normoglykemi utviklet dysglykemi etter kirurgi. Totalt 8 av 14 (57\%) pasienter med prediabetes i livsstilsgruppen ble normoglykemiske, mens 6 av 71 ( $9 \%$ ) med normoglykemi utviklet prediabetes. 
Det ble registrert to tidlige (<6 uker) mindre alvorlige kirurgiske komplikasjoner. Det var ingen statistisk signifikant reduksjon i gjennomsnittlig hemoglobin, albumin eller vitaminer og mineraler ved ettårskontrollen, men 4 (10\%) hadde anemi, 8 (21\%) jernmangel og $4(10 \%)$ lavt vitamin $B_{12}$. Totalt 20 av 33 (61\%) pasienter hadde lavt totimers-blodsukker (< $2,8 \mathrm{mmol} / \mathrm{L}$ ) etter en glukosetoleransetest (tabell 4). Både beinmineralinnhold (BMC) og beinmineraltetthet (BMD-z-skår) falt signifikant, i gjennomsnitt 3,5\% (BMC) og 0,5 standardavvik (BMD-z-skår), begge p-verdier < o,oo1 (tabell 4). Én pasient hadde BMD-z-skår $<-2,0(-2,1)$ etter ett år.

\section{Tabell 4}

Vitaminer, mineraler, albumin, hemoglobin, beinhelse og hypoglykemi etter $75 \mathrm{~g}$ glukose ved glukosebelastningstest målt før oppstart av behandling og etter ett år hos inkluderte ungdommer med sykelig overvekt som ble behandlet med gastrisk bypass kombinert med livsstilsintervensjon ved Senter for sykelig overvekt i Vestfold i perioden 8.10.2009-19.4.2018 og som møtte til ettårskontroll. Gjennomsnitt (SD) eller antall (\%).

\begin{tabular}{|c|c|c|c|c|}
\hline Utfallsmål & Utgangsverdi & Ettårsverdi $^{1}$ & $\begin{array}{l}\text { Endring } \\
(95 \% \mathrm{KI})\end{array}$ & P-verdi $^{2}$ \\
\hline \multicolumn{5}{|l|}{ Hemoglobin og anemi } \\
\hline Hemoglobin (g/dL) & $13,7(1,1)$ & $13,5(1,5)$ & $\begin{array}{r}-0,19 \\
(-0,50 \text { til } \\
0,11) \\
\end{array}$ & 0,21 \\
\hline $\begin{array}{l}\mathrm{Hb}<12 \mathrm{~g} / \mathrm{dL} \text { jenter} /<13 \mathrm{~g} / \mathrm{dL} \\
\text { gutter }\end{array}$ & $1 / 39(2,6 \%)$ & $4 / 39(10 \%)$ & & 0,63 \\
\hline Albumin $(\mathrm{g} / \mathrm{L})$ & $41,9(3,0)$ & $40,9(3,6)$ & $\begin{array}{r}-1,0(-2,02 \\
\text { til } 0,07)\end{array}$ & 0,067 \\
\hline \multicolumn{5}{|l|}{ Jern og jernmangel } \\
\hline Ferritin $(\mu \mathrm{g} / \mathrm{L})$ & $50(30)$ & $47(42)$ & $\begin{array}{r}-3(-16 \text { til } \\
10) \\
\end{array}$ & 0,65 \\
\hline Ferritin $<15 \mu \mathrm{g} / \mathrm{L}$ & $0 / 39(0 \%)$ & $8 / 39(21 \%)$ & & NA \\
\hline \multicolumn{5}{|l|}{ Vitaminer, PTH og kalsium } \\
\hline Tiamin (nmol/L) & $165(32)$ & $158(33)$ & $\begin{array}{r}-7(-16 \text { til } \\
2) \\
\end{array}$ & 0,14 \\
\hline Vitamin $\mathrm{B}_{12}(\mathrm{pmol} / \mathrm{L})$ & $304(126)$ & $467(381)$ & $\begin{array}{r}163(48 \text { til } \\
278) \\
\end{array}$ & 0,007 \\
\hline Vitamin $B_{12}<150 \mathrm{pmol} / \mathrm{L}$ & $1 / 39(2,6 \%)$ & $4 / 38(10 \%)$ & & 0,38 \\
\hline Vitamin D (nmol/L) & $48(20)$ & $48(19)$ & $0(-7$ til 6$)$ & 0,92 \\
\hline Vitamin $\mathrm{D}<50 \mathrm{nmol} / \mathrm{L}$ & $23 / 38(59 \%)$ & $22 / 37(56 \%)$ & & 1,0 \\
\hline $\begin{array}{l}\text { Kalsium, albuminkorrigert } \\
(\mathrm{mmol} / \mathrm{L})\end{array}$ & $2,39(0,07)$ & $2,41(0,05)$ & $\begin{array}{r}0,013 \\
(-0,009 \text { til } \\
0,035) \\
\end{array}$ & 0,24 \\
\hline $\begin{array}{l}\text { Paratyreoideahormon (PTH) } \\
(\mathrm{pmol} / \mathrm{L})\end{array}$ & $5,2(1,8)$ & $4,7(1,2)$ & $\begin{array}{r}-0,3(-0,8 \\
\text { til } 0,2) \\
\end{array}$ & 0,21 \\
\hline $\begin{array}{l}\text { Sekundær } \\
\text { hyperparatyreoidisme }\end{array}$ & $3 / 39(8 \%)$ & $2 / 38(5 \%)$ & & 1,0 \\
\hline \multicolumn{5}{|l|}{ Beinhelse } \\
\hline Beinmineralinnhold, BMC (g) & $2642(283)$ & $2590(361)$ & $\begin{array}{r}-92(-134 \text { til } \\
-50) \\
\end{array}$ & $<0,001$ \\
\hline $\begin{array}{l}\text { Beinmineraltetthet, BMD-Z- } \\
\text { skår }\end{array}$ & $1,19(1,08)$ & $0,67(1,07)$ & $\begin{array}{r}-0,51 \\
(-0,66 \text { til } \\
-0,36) \\
\end{array}$ & $<0,001$ \\
\hline \multicolumn{5}{|l|}{ Hypoglykemi } \\
\hline $\begin{array}{l}\text { Glukose etter } \\
\text { glukosebelastningstest < } \\
2,8 \mathrm{mmol} / \mathrm{L}\end{array}$ & 0/37 (0 \%) & 20/33 (61\%) & & NA \\
\hline
\end{tabular}

${ }^{1}$ Alle utgangsverdier og ettårsverdier analysert for minst 37 av 39 (95\%) pasienter (unntatt s- 
glukose etter oral glukosebelastningstest ved ettårsoppfølgingen).

${ }^{2}$ Paret t-test eller McNemars test.

\section{Diskusjon}

Resultatene fra den ikke-randomiserte 4XL-studien viste betydelig større vektreduksjon etter ett år og bedring av kardiometabolske risikofaktorer etter gastrisk bypass kombinert med livsstilsbehandling enn etter livsstilsbehandling alene. Det ikke-randomiserte studiedesignet, et relativt lavt antall opererte pasienter og kort oppfølgingstid gjør imidlertid at vi ikke kan vurdere om risikoen for eventuelle langtidskomplikasjoner oppveies av fordelene med vektreduksjon. Vi kan heller ikke utelukke systematiske skjevheter i både seleksjon og frafall mellom behandlingsgruppene som kunne ha påvirket utfallet, med påfølgende redusert intern validitet og generaliserbarhet.

Det finnes (per 9. oktober 2020) kun én publisert randomisert kontrollert studie der man har sammenliknet effekten av livsstilsbehandling med vektreduserende kirurgi hos ungdom, men da med en operasjonstype (båndkirurgi) som sjelden brukes (14). I en pågående randomisert kontrollert studie av 13-16-åringer med BMI > $35 \mathrm{~kg} / \mathrm{m}^{2}$ sammenliknes laparoskopisk Roux-en-Y gastrisk bypass med kalorirestriksjon (lavaloridiett) for å se hvilke effekter disse har på BMI. Resultatene herfra vil kunne styrke kunnskapsgrunnlaget ytterligere (https://clinicaltrials.gov/ct2/show/NCTo2378259).

Våre resultater samsvarer med funn fra to ikke-randomiserte studier som viste om lag 30 \% vektreduksjon henholdsvis ett år og to år etter gastrisk bypass $(15,16)$. Den svenske AMOSstudien sammenliknet gastrisk bypass med konvensjonell behandling og viste $31-32 \%$ vekttap i kirurgigruppen versus $3 \%$ vekt $ø$ kning i kontrollgruppen (16). En amerikansk studie viste om lag $30 \%$ vekttap ett år og to år etter bypassoperasjon (15). Den betydelige bedringen av kardiometabolske risikofaktorer i kirurgigruppen bekrefter resultater fra observasjonelle studier $(16,17)$.

To (5\%) postoperative komplikasjoner ble registrert, og dette er i samsvar med internasjonal erfaring $(16,18)$. Risikoen for langtidskomplikasjoner etter vektreduserende kirurgi hos ungdom er generelt dårlig dokumentert (9) og er heller ikke undersøkt i denne analysen.

Anemi og vitamin- og mineralmangler er kjente bivirkninger etter gastrisk bypass $(7,16)$. Gjennomsnittlig nivå av hemoglobin, ferritin, kalsium, vitamin D og vitamin $B_{12}$ sank imidlertid ikke signifikant etter ett år i denne studien. Ved ettårskontrollen hadde likevel flere pasienter anemi, jernmangel eller lavt vitamin $B_{12}$-nivå (tabell 4), og om lag 2 av 3 pasienter (61\%) hadde totimers-hypoglykemi etter glukosebelastning (blodsukker < 2,8 mmol/L). Forekomsten av totimers- hypoglykemi var høyere enn vist hos voksne (19, 20), og lavere alder er en risikofaktor (21). Ingen frakturer ble registrert, og beinmineralmålinger viste ikke (gjennomsnittlig) fall i beintetthet til under forventet for alderen. Det er likevel bekymringsfullt at gastrisk bypass er assosiert med $ø$ kende frakturrisiko (22) og postprandial hypoglykemi. Livsvarig oppfølging med forebyggende tiltak og diagnostikk synes nødvendig.

4XL-studien er pågående, og det er planlagt ti års oppfølging. Det er en styrke ved studien at intervensjonsgruppen sammenliknes med en aktivt behandlet kontrollgruppe, der deltakerne tilfredsstiller felles inklusjonskriterier. I tillegg gjennomføres studien i regi av et senter med spesialkompetanse på familiebasert livsstilsbehandling av ungdom, vektreduserende kirurgi og klinisk forskning. Kompleksiteten i vurderingen og oppfølgingen av denne pasientgruppen krever et sømløst og tett samarbeid mellom helsepersonell som er spesialisert i behandling av barnefedme og kirurger med ekspertise i vektreduserende kirurgi.

Svakheter er et relativt lavt antall pasienter i kirurgigruppen, lang rekrutteringsperiode 
samt forskjeller mellom gruppene i utgangsverdier for alder (17 år vs. 16 år) og BMI $\left(45,6 \mathrm{~kg} / \mathrm{m}^{2}\right.$ vs. $\left.43,3 \mathrm{~kg} / \mathrm{m}^{2}\right)$. Sistnevnte har imidlertid hatt liten betydning for forskjellene i endring av det primære utfallsmålet, som er justert for utgangsvekt i de primære analysene, og ytterligere justering for alder ga ingen endring av resultatene. Selv om utvalgsstørrelsen var lavere enn planlagt ( $\mathrm{n}=50$ i kirurgigruppen), var frafallet ( $5 \%$ ) lavere enn forventet (30\%). Studien hadde derfor tilstrekkelig styrke til å kunne besvare det primære forskningsspørsmålet om vektreduksjon når 39 pasienter hadde møtt til ettårskontroll.

En nylig publisert metaanalyse viste at helserelatert livskvalitet ble betydelig bedret spesielt de første årene etter kirurgi hos unge, men at data på langtidsforekomsten av andre psykososiale og mentale helseaspekter manglet (23). Langtidsresultater fra AMOS-studien viser at mentale helseproblemer ikke nødvendigvis avtar etter gastrisk bypass hos unge, og at behovet for psykiatrisk hjelp kan være større enn hos ikke-opererte (24). Helserelatert livskvalitet, psykologiske aspekter, spiseatferd og langtidskomplikasjoner er temaer for senere analyser og publikasjoner fra 4XL-studien.

Våre resultater bekrefter at laparoskopisk Roux-en-Y gastrisk bypass kan gjennomføres med tilfredsstillende vektreduksjon, bedring av kardiometabolske risikofaktorer og lav forekomst av tidlige postoperative komplikasjoner. Studien tyder også på at forekomsten av bivirkninger og komplikasjoner på kort sikt likner tilsvarende funn hos voksne (7), men studien er likevel for liten til å konkludere sikkert om forekomst og alvorlighetsgrad av disse. Langtidseffekter og langtidskomplikasjoner etter vektreduserende kirurgi hos ungdom er imidlertid fortsatt dårlig dokumentert (9). På generelt grunnlag er det derfor vanskelig å vite om fedmekirurgi bør tilbys flere unge med sykelig overvekt, eller om man heller burde anbefale å vente til voksen alder. Argumenter for fedmekirurgi i ungdomsalderen er mulighetene for et betydelig vekttap, bedre livskvalitet samt redusert risiko for fremtidig fedmerelatert sykdom. Argumenter mot er risikoen for alvorlige komplikasjoner, anemi, hypoglykemi, vitamin- og mineralmangler samt psykiske plager.

\section{HOVEDFUNN}

Ungdom behandlet med laparoskopisk gastrisk bypassoperasjon kombinert med livsstilsintervensjon hadde betydelig større ett års vekttap (31\%) enn ungdom behandlet med livsstilsintervensjon alene.

Operasjon, men ikke livsstilsintervensjon, var assosiert med betydelig bedring av kardiometabolske risikofaktorer.

Relativt mange opererte pasienter hadde anemi (10 \%), jernmangel (21\%) og lave vitamin $B_{12}{ }^{-}$ verdier (10\%) etter ett år.

20 av 33 pasienter (61\%) som fikk utført glukosebelastning, hadde lavt blodsukker etter to timer.

\section{LITTERATUR:}

1. Must A, Strauss RS. Risks and consequences of childhood and adolescent obesity. Int J Obes Relat Metab Disord 1999; 23 (suppl 2): S2-11. [PubMed][CrossRef]

2. Llewellyn A, Simmonds M, Owen CG et al. Childhood obesity as a predictor of morbidity in adulthood: a systematic review and meta-analysis. Obes Rev 2016; 17: 56-67. [PubMed][CrossRef]

3. Steinbeck KS, Lister NB, Gow ML et al. Treatment of adolescent obesity. Nat Rev Endocrinol 2018; 14: 331-44. [PubMed][CrossRef]

4. Skodvin VA, Lekhal S, Kommedal KG et al. Livsstilsbehandling av barn og ungdom med alvorlig fedme - resultater etter ett år. Tidsskr Nor Legeforen 2020; 11: 901-7.

5. Al-Khudairy L, Loveman E, Colquitt JL et al. Diet, physical activity and behavioural interventions for 
the treatment of overweight or obese adolescents aged 12 to 17 years. Cochrane Database Syst Rev 2017; 6: CDo12691. [PubMed][CrossRef]

6. Hofs $\emptyset$ D, Fatima F, Borgeraas H et al. Gastric bypass versus sleeve gastrectomy in patients with type 2 diabetes (Oseberg): a single-centre, triple-blind, randomised controlled trial. Lancet Diabetes Endocrinol 2019; 7: 912-24. [PubMed][CrossRef]

7. Jakobsen GS, Småstuen MC, Sandbu R et al. Association of Bariatric Surgery vs Medical Obesity Treatment With Long-term Medical Complications and Obesity-Related Comorbidities. JAMA 2018; 319: 291-301. [PubMed][CrossRef]

8. Treadwell JR, Sun F, Schoelles K. Systematic review and meta-analysis of bariatric surgery for pediatric obesity. Ann Surg 2008; 248: 763-76. [PubMed][CrossRef]

9. Ruiz-Cota P, Bacardí-Gascón M, Jiménez-Cruz A. Long-term outcomes of metabolic and bariatric surgery in adolescents with severe obesity with a follow-up of at least 5 years: A systematic review. Surg Obes Relat Dis 2019; 15: 133-44. [PubMed][CrossRef]

10. Expert Panel on Integrated Guidelines for Cardiovascular Health and Risk Reduction in Children and AdolescentsNational Heart, Lung, and Blood Institute.. Expert panel on integrated guidelines for cardiovascular health and risk reduction in children and adolescents: summary report. Pediatrics 2011; 128 (suppl 5): S213-56. [PubMed][CrossRef]

11. American Diabetes Association.. 2. Classification and Diagnosis of Diabetes: Standards of Medical Care in Diabetes-2020. Diabetes Care 2020; 43 (suppl 1): S14-31. [PubMed][CrossRef]

12. Dong Y, Song Y, Zou Z et al. Updates to pediatric hypertension guidelines: influence on classification of high blood pressure in children and adolescents. J Hypertens 2019; 37: 297-306. [PubMed][CrossRef]

13. Johansen MJ, Gade J, Stender S et al. The Effect of Overweight and Obesity on Liver Biochemical Markers in Children and Adolescents. J Clin Endocrinol Metab 2020; 105: dgzo10. [PubMed][CrossRef]

14. O'Brien PE, Sawyer SM, Laurie C et al. Laparoscopic adjustable gastric banding in severely obese adolescents: a randomized trial. JAMA 2010;303: 519-26. [PubMed][CrossRef]

15. Inge TH, Courcoulas AP, Jenkins TM et al. Weight Loss and Health Status 3 Years after Bariatric Surgery in Adolescents. N Engl J Med 2016; 374: 113-23. [PubMed][CrossRef]

16. Olbers T, Gronowitz E, Werling M et al. Two-year outcome of laparoscopic Roux-en-Y gastric bypass in adolescents with severe obesity: results from a Swedish Nationwide Study (AMOS). Int J Obes 2012; 36: 1388-95. [PubMed][CrossRef]

17. Black JA, White B, Viner RM et al. Bariatric surgery for obese children and adolescents: a systematic review and meta-analysis. Obes Rev 2013; 14: 634-44. [PubMed][CrossRef]

18. Arafat M, Norain A, Burjonrappa S. Characterizing Bariatric Surgery Utilization and Complication Rates in the Adolescent Population. J Pediatr Surg 2019; 54: 288-92. [PubMed][CrossRef]

19. Hofs $\varnothing$ D, Nordstrand N, Johnson LK et al. Obesity-related cardiovascular risk factors after weight loss: a clinical trial comparing gastric bypass surgery and intensive lifestyle intervention. Eur J Endocrinol 2010; 163: 735-45. [PubMed][CrossRef]

20. Pigeyre M, Vaurs C, Raverdy V et al. Increased risk of OGTT-induced hypoglycemia after gastric bypass in severely obese patients with normal glucose tolerance. Surg Obes Relat Dis 2015; 11: 573-7. [PubMed][CrossRef]

21. Hofsø D, Birkeland KI, Holst JJ et al. Gastric bypass surgery has a weight-loss independent effect on post-challenge serum glucose levels. Diabetol Metab Syndr 2015; 7: 69. [PubMed][CrossRef]

22. Paccou J, Martignène N, Lespessailles E et al. Gastric Bypass But Not Sleeve Gastrectomy Increases Risk of Major Osteoporotic Fracture: French Population-Based Cohort Study. J Bone Miner Res 2020; 35: 1415-23. [PubMed][CrossRef]

23. Trooboff SW, Stucke RS, Riblet NB et al. Psychosocial Outcomes Following Adolescent Metabolic and Bariatric Surgery: a Systematic Review and Meta-Analysis. Obes Surg 2019; 29:3653-64. [PubMed][CrossRef]

24. Järvholm K, Bruze G, Peltonen M et al. 5-year mental health and eating pattern outcomes following bariatric surgery in adolescents: a prospective cohort study. Lancet Child Adolesc Health 2020; 4: 
Publisert: 9. november 2020. Tidsskr Nor Legeforen. DOI:10.4045/tidsskr.20.0526

Mottatt 11.6.2020, første revisjon innsendt 4.10.2020, godkjent 9.10.2020.

() Tidsskrift for Den norske legeforening 2020. Lastet ned fra tidsskriftet.no 